\title{
Implications of Secondary Treated Distillery Effluent Irrigation on Soil Cellulase and Urease Activities
}

\author{
Devendra Mani Tripathi, Smriti Tripathi, B. D. Tripathi* \\ Banaras Hindu University, Varanasi, India. \\ Email: thevendramanitripathi@gmail.com,smrititripathibhu@gmail.com, *bdtripathi1947@rediffmail.com
}

Received March 30 ${ }^{\text {th }}, 2011$; revised May $3^{\text {rd }}, 2011$; accepted June $14^{\text {th }}, 2011$.

\begin{abstract}
Currently distillery effluents have attracted worldwide attention for their application in agricultural land. The present investigation deals with the effect of application of various dosages of distillery effluent irrigation on soil physicochemical, Cellulase and Urease activities in a tropical agricultural field. Experiment was designed in factorial model by using randomized block design. Soil cores were sampled from the selected pits of both polluted and non polluted (control) sites. Majority of soil physicochemical properties (e.g. silt, clay, electrical conductivity, organic matter, total nitrogen contents, cellulase and urease activities) were significantly higher in the samples from polluted site than the non polluted site just after 15 to 30 days of incubation. Although application of effluents at lower rate substantially increased the enzyme activities, the same decreased at high effluent concentration. Prolonged incubation period resulted in gradual suppression of enzyme activity in both polluted and nonpolluted soil samples. Thus, the present investigation suggest that with the passage of time substrate for enzyme activity decreases which in association with residual toxicity resulted in the reduced enzyme activity.
\end{abstract}

Keywords: Distillery Effluent, Cellulase, Urease, BOD, COD, Electrical Conductivity

\section{Introduction and Methods}

Application of distillery effluent on degraded soils is one of the most economical resources for the soil fertility amelioration through improvement in soil water-holding capacity, texture, structure, nutrients retention, roots penetration, and reduction in soil acidity (O'Brien et al. 2002; Aravena et al. 2007; Rato Nunes et al. 2008). Now a day in our country due to the increasing number of sugar mills and distillery units, application of distillery effluent on soil nearly become mandatory.

However, its application in soil also results in environmental problems (Cruz et al. 1991) because apart from organic content and nutrients, sludge also includes heavy metals, colored compounds, dissolved inorganic salts, chlorinated lignin, and phenolic derivatives (Chandra et al. 2004). These compounds may change soil physicochemical properties and soil enzyme activities. Soil enzymes activities play an essential role in catalyzing reactions which are necessary for the decomposition of organic matter and nutrient cycling in ecosystems, involving a range of plants, microorganisms, animals and their debris (Johansson et al., 2000). Therefore, changes in enzymes activity could alter the availability of nutrients for plant uptake and these changes are potentially sensitive indicators of soil quality (Ajwa et al., 1999; Albiach et al., 2000).

Dick and Tabatabai (1992) expressed that measurements of several enzymatic activities have been used to establish indices of soil biological activity. Cellulase and Urease are the two important enzymes which play a significant role in soil environment. Cellulase is a core enzyme which contains exo, endo and $\beta$-glucosidases. This enzyme synergistically acts on cellulose, the most abundant polysaccharide of plant cell walls and representing significant input to soils (Richards, 1987). Urease catalyzes the hydrolysis of urea and amides to carbon dioxide and ammonia. It acts on carbon-nitrogen (C-N) bonds other than peptide linkage (Bremner and Mulvaney, 1978; Karaca et al., 1999). Urease is a constitutive intracellular enzyme with three subunits of $\alpha, \beta$ and $\gamma$ and two nickel ions. Furthermore, liberation of these enzymes by microbes during litter decomposition may be influenced by 
too many factors like temperature, $\mathrm{pH}$ and substrate concentration in the soil environment (Linkins et al., 1984).

Therefore, the main objectives of the present study were to evaluate the effect of different application rates of distillery effluent, on Urease and Cellulase activity in the test and the control soil samples.

\section{Materials and Methods}

\subsection{Soil Collection and Soil Physico Chemical Property measurement}

This study was performed at the agricultural farm at the Narang distillery $\left(26^{\circ} 52^{\prime} \mathrm{N}, 82^{\circ} 08^{\prime} \mathrm{E}\right.$ and $98 \mathrm{~m}$ above the mean sea level) in northern India. Figure 1, indicates the sampling site. Experiment was designed in randomized block design with four replicate plots of $5 \mathrm{~m} \times 5 \mathrm{~m}$ size for various doses of effluent amendment. Likewise four un-amended plots were also established as control. Composite soil samples were collected from A-horizon (0 - 20 $\mathrm{cm}$ soil depth) of the plot without any crop at different time intervals from the experimental field. The experimental soil is an inceptisol with a pale brown colour, and sandy loam texture. Ten soil samples were collected and composited into one sample then packed in sterile polythene bags and were stored at $4^{\circ} \mathrm{C}$ in the dark and maintained at $50 \%$ water holding capacity then it was sieved through a $2 \mathrm{~mm}$-pore size sieve before use. The physicochemical properties of amended and un-amended soil, including organic matter, cations exchange capacity etc. were estimated using standard methods (Kalra et al. 1988, APHA 2005). Moisture content was determined by wet oxidation method. Soil $\mathrm{pH}$ was determined using an electrode and a 1:1 soil/water mixture (Thomas, 1996). Electrical conductivity was estimated by the addition of $100 \mathrm{ml}$ of water to $1 \mathrm{~g}$ of soil sample in the conductivity meter. The method described by Johnson and Ulrich (1960) was employed for estimating 70\% water holding capacity. Organic $\mathrm{C}$ and Total Nitrogen content was measured by using the Walkely and Black method (Nelson and Sommers, 1996), and Microkjeldhal method (Jackson, 1973), respectively. The extractable heavy metal concentrations in soil samples were measured by atomic absorption spectrometry after extraction with aquaregia.

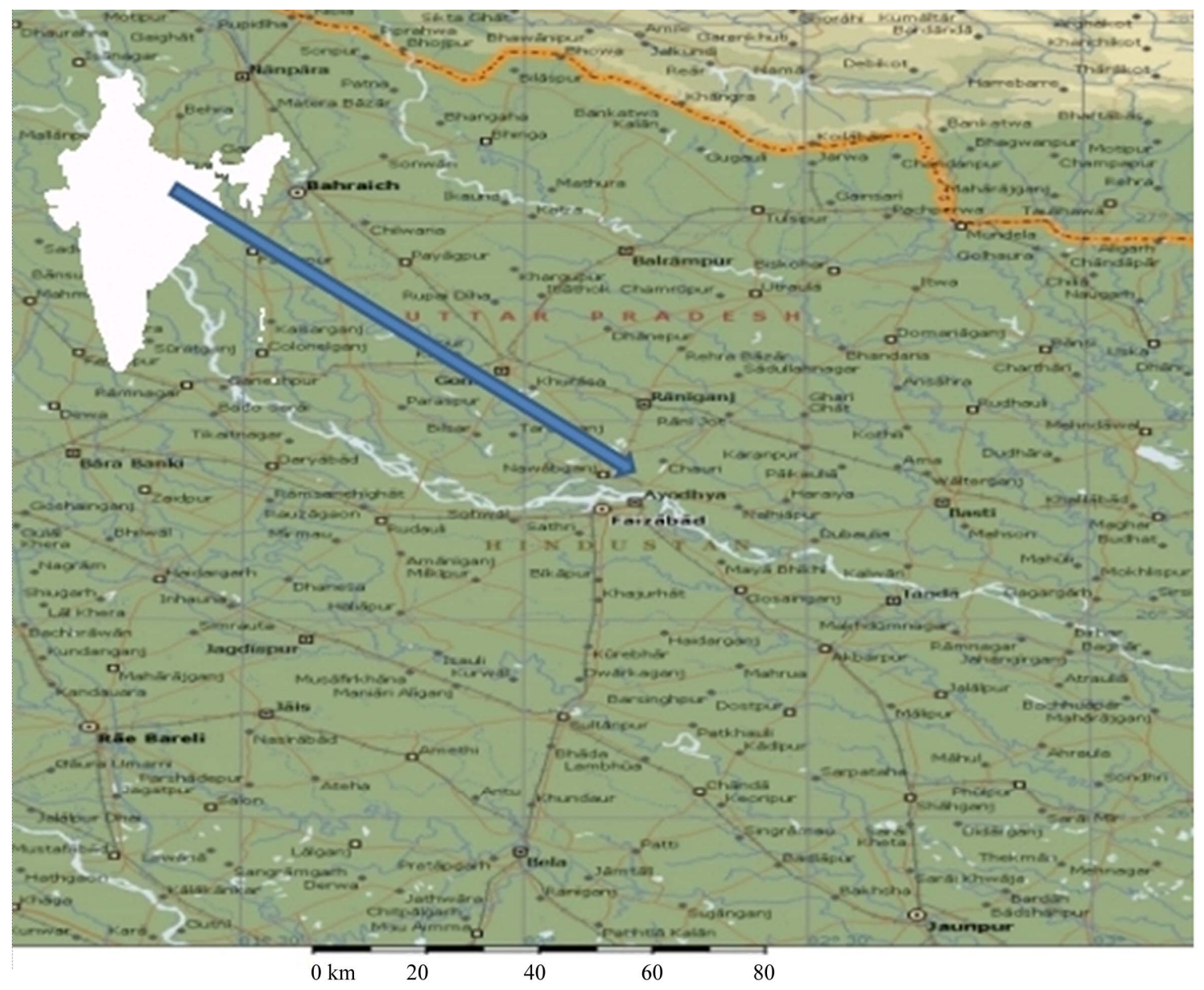

Figure 1. Sampling site. 


\subsection{Enzyme Activity Measurement}

Both the amended and control soils were moistened to $70 \%$ soil water holding capacity and incubated for 90 days, at $28 \pm 4^{\circ} \mathrm{C}$ in a large size vessel. Soil samples in triplicate were taken after $0,15,30,45,60,75$ and 90 days of incubation. For Cellulase activity measurement, 5 $\mathrm{g}$ of soil samples were treated with $0.5 \mathrm{ml}$ of toluene in $50 \mathrm{ml}$ Erlenmeyer flasks, mixed thoroughly, and after 15 minutes treated with $10 \mathrm{ml}$ of acetate buffer of $0.5 \mathrm{M}(\mathrm{pH}$ $5.9)$ and $10 \mathrm{ml}$ of $1 \%$ carboxy methyl cellulose (CMC). After $30 \mathrm{~min}$ of incubation, approximately $50 \mathrm{ml}$ of distilled water was added, filtered by Whatman No.1 filter paper and the volume of the filtrate was made upto 100 $\mathrm{ml}$ with distilled water (Pancholy and Rice 1973). The resultant filtrate was used for the determination of reducing sugar content by Nelson-Somagyi method (1944) in a digital spectrophotometer. Cellulase activity was expressed in terms of micrograms of Glucose Equivalents per $\mathrm{g}$ of soil per $30 \mathrm{~min}\left(\mu \mathrm{g} \mathrm{GE} \mathrm{g}^{-1} 30 \mathrm{~m}^{-1}\right)$.

For Urease activity, determination citrate buffer $(0.75$ $\mathrm{ml}$ ) of $\mathrm{pH} 6.7,1 \mathrm{ml}$ of $10 \%$ urea substrate solution and $0.25 \mathrm{ml}$ toluene were added to $1 \mathrm{~g}$ of soil sample and incubated for $3 \mathrm{~h}$ at $37^{\circ} \mathrm{C}$. The formation of ammonium was determined spectrophotometrically and the results were expressed as $\mu \mathrm{g} \mathrm{NH} 4+\mathrm{g}-1$ dry soil (Hoffmann and Teicher 1961).

\section{Results and Discussions}

\subsection{Soil Physicochemical Characters}

Effluent discharged soil samples underwent significant changes (Table 1 and Table 2) in all measured parameters in comparison to control. Soil texture in terms of percentage of sand, silt and clay were 31.6, 56.4 and 12.0 in the control soils, respectively. The results indicated that distillery effluent discharged soil had relatively higher clay and silt contents than the control soil Other studies have found the same, like long term application of sewage effluents (Abdelnainm et al., 1987) and cotton ginning mill effluents (Narasimha et al., 1999). However, increased water holding capacity and electrical conductivity in the test soil may be due to accumulation of organic wastes and salts in the distillery effluents. Likewise, similar results were observed in soils discharged with effluents from cotton ginning mills (Narasimha et al., 1999), paper mills (Medhi et al., 2005) and sewage irrigated soils (Renukaprasanna et al., 2002). The $\mathrm{pH}$ of all the test samples increased upto 8.2 from 6.8 upon the release of effluents. Electrical conductivity, organic matter, Phosphate, Sulphate, Phenol and Total Nitrogen contents were higher in the test samples over the control samples and were $2.02 \mathrm{mS} \cdot \mathrm{cm}^{-1}, 3.72 \%, 432 \mathrm{mg} \cdot \mathrm{kg}^{-1}$, $321.36 \mathrm{mg} \cdot \mathrm{kg}^{-1}, 102.45 \mathrm{mg} \cdot \mathrm{kg}^{-1}$ and $116.56 \mathrm{mg} \cdot \mathrm{kg}^{-1}$ of

Table 1. Physico-chemical characteristics and metal contents in Distillery effluent.

\begin{tabular}{cc}
\hline Parameter & Values for Distillery Effluent \\
\hline $\mathrm{pH}$ & $9.2 \pm 0.45$ \\
$\mathrm{COD}\left(\mathrm{mg} \cdot \mathrm{L}^{-1}\right)$ & $56800 \pm 127.83$ \\
BOD $\left(\mathrm{mg} \cdot \mathrm{L}^{-1}\right)$ & $22500 \pm 213.54$ \\
$\mathrm{TSS}\left(\mathrm{mg} \cdot \mathrm{L}^{-1}\right)$ & $12560 \pm 315.56$ \\
TDS $\left(\mathrm{mg} \cdot \mathrm{L}^{-1}\right)$ & $13760 \pm 229.56$ \\
Sulphate $\left(\mathrm{mg} \cdot \mathrm{L}^{-1}\right)$ & $785.80 \pm 34.67$ \\
Phosphate $\left(\mathrm{mg} \cdot \mathrm{L}^{-1}\right)$ & $626.65 \pm 58.34$ \\
Potassium $\left(\mathrm{mg} \cdot \mathrm{L}^{-1}\right)$ & $369.88 \pm 74.83$ \\
Chloride $\left(\mathrm{mg} \cdot \mathrm{L}^{-1}\right)$ & $278.67 \pm 26.78$ \\
Total Nitrogen $\left(\mathrm{mg} \cdot \mathrm{L}^{-1}\right)$ & $412.78 \pm 15.89$ \\
Electrical Conductivity $(\mathrm{mS} \cdot \mathrm{cm}$ & $15.84 \pm 1.05$ \\
Copper $(0.20) *\left(\mathrm{mg} \cdot \mathrm{L}^{-1}\right)$ & $2.78 \pm 0.63$ \\
Cadmium $(0.01) *\left(\mathrm{mg} \cdot \mathrm{L}^{-1}\right)$ & $3.56 \pm 0.04$ \\
Chromium $(0.10)^{*}\left(\mathrm{mg} \cdot \mathrm{L}^{-1}\right)$ & $5.88 \pm 0.56$ \\
Zinc $(2.0) *\left(\mathrm{mg} \cdot \mathrm{L}^{-1}\right)$ & $34.27 \pm 1.49$ \\
Iron $(5.0)^{*}\left(\mathrm{mg} \cdot \mathrm{L}^{-1}\right)$ & $218.78 \pm 7.98$ \\
Nickel $(0.20)^{*}\left(\mathrm{mg} \cdot \mathrm{L}^{-1}\right)$ & $7.89 \pm 0.85$ \\
Manganese $(0.20) *\left(\mathrm{mg} \cdot \mathrm{L}^{-1}\right)$ & $4.92 \pm 0.43$ \\
Lead $\left(5.0 * *\left(\mathrm{mg} \cdot \mathrm{L}^{-1}\right)\right.$ & $2.56 \pm 0.18$ \\
\hline
\end{tabular}

All the values are means of three replicates \pm S.D; *Permissible limits for metals in agricultural land irrigation water (Rowe and Abdel-Magid,1995). 
Table 2. Physicochemical properties of experimental unamended soil and soil amended with different dosages of distillery effluent (values represent mean $\mathrm{n}=3 \pm \mathrm{SE}$ ). All values presented in $\mathrm{mg} \cdot \mathrm{kg}^{-1}$ except electrical conductivity $\left(\mathrm{mS} \cdot \mathrm{cm}^{-1}\right)$ and $\mathrm{pH}$.

\begin{tabular}{|c|c|c|c|c|}
\hline Parameter & Soil & $10 \%$ & $50 \%$ & $100 \%$ \\
\hline $\mathrm{pH}$ & $6.8 \pm 0.27$ & $7.3 \pm 0.17$ & $8.47 \pm 0.35$ & $8.2 \pm 0.31$ \\
\hline Sand $(\%)$ & $31.6 \pm 2.56$ & $18.35 \pm 0.54$ & $13.00 \pm 1.05$ & $8.5 \pm 1.9$ \\
\hline Silt (\%) & $56.4 \pm 3.56$ & $69.06 \pm 2.67$ & $71.50 \pm 4.76$ & $73.87 \pm 4.22$ \\
\hline Clay $(\%)$ & $12.0 \pm 1.05$ & $12.75 \pm 0.81$ & $15.46 \pm 1.54$ & $18.20 \pm 2.50$ \\
\hline Moisture (\%) & $70 \pm 1.67$ & $71 \pm 1.62$ & $72 \pm 3.43$ & $74 \pm 3.22$ \\
\hline Organic matter $(\%)$ & $1.09 \pm 0.03$ & $1.89 \pm 0.056$ & $2.86 \pm 0.86$ & $3.72 \pm 0.75$ \\
\hline $\mathrm{EC}\left(\mathrm{mS} \cdot \mathrm{cm}^{-1}\right)$ & $1.55 \pm 0.024$ & $1.85 \pm 0.12$ & $1.93 \pm 0.083$ & $2.02 \pm 0.12$ \\
\hline Phosphate $\left(\mathrm{mg} \cdot \mathrm{kg}^{-1}\right)$ & $265 \pm 2.88$ & $316 \pm 3.27$ & $383 \pm 6.92$ & $432 \pm 8.43$ \\
\hline Sulphate $\left(\mathrm{mg} \cdot \mathrm{kg}^{-1}\right)$ & $55.68 \pm 1.53$ & $188.67 \pm 1.82$ & $278.50 \pm 6.45$ & $321.36 \pm 8.77$ \\
\hline Phenol $\left(\mathrm{mg} \cdot \mathrm{kg}^{-1}\right)$ & $3.09 \pm 0.21$ & $34.78 \pm 1.47$ & $85.02 \pm 8.82$ & $102.45 \pm 11.23$ \\
\hline Total Nitrogen $\left(\mathrm{mg} \cdot \mathrm{kg}^{-1}\right)$ & $56.76 \pm 2.34$ & $73.34 \pm 2.66$ & $92.32 \pm 7.33$ & $116.56 \pm 13.08$ \\
\hline Sodium $\left(\mathrm{mg} \cdot \mathrm{kg}^{-1}\right)$ & $13.67 \pm 0.82$ & $29.14 \pm 0.85$ & $48.45 \pm 2.18$ & $69.44 \pm 2.07$ \\
\hline Chloride $\left(\mathrm{mg} \cdot \mathrm{kg}^{-1}\right)$ & $96.72 \pm 1.51$ & $109.28 \pm 3.57$ & $168.45 \pm 8.89$ & $211.14 \pm 9.19$ \\
\hline Magnesium $\left(\mathrm{mg} \cdot \mathrm{kg}^{-1}\right)$ & $9.48 \pm 0.32$ & $9.88 \pm 0.48$ & $14.42 \pm 0.77$ & $17.22 \pm 0.63$ \\
\hline Calcium $\left(\mathrm{mg} \cdot \mathrm{kg}^{-1}\right)$ & $11.55 \pm 0.21$ & $19.33 \pm 0.64$ & $45.3 \pm 2.21$ & $62.12 \pm 3.46$ \\
\hline Aluminum $\left(\mathrm{mg} \cdot \mathrm{kg}^{-1}\right)$ & $3.94 \pm 0.27$ & $4.34 \pm 0.47$ & $8.12 \pm 0.34$ & $10.88 \pm 0.64$ \\
\hline Potassium $\left(\mathrm{mg} \cdot \mathrm{kg}^{-1}\right)$ & $44.39 \pm 0.017$ & $72.82 \pm 0.13$ & $108.55 \pm 0.41$ & $183.33 \pm 0.88$ \\
\hline Cadmium (mg kg $\left.{ }^{-1}\right)$ & $0.06 \pm 0.0021$ & $0.32 \pm 0.016$ & $1.02 \pm 0.042$ & $1.38 \pm 0.04$ \\
\hline Chromium $\left(\mathrm{mg} \cdot \mathrm{kg}^{-1}\right)$ & $0.89 \pm 0.014$ & $2.88 \pm 0.065$ & $2.92 \pm 0.12$ & $3.08 \pm 0.07$ \\
\hline Copper $\left(\mathrm{mg} \cdot \mathrm{kg}^{-1}\right)$ & $2.25 \pm 0.043$ & $18.22 \pm 0.78$ & $62.88 \pm 3.27$ & $88.17 \pm 4.77$ \\
\hline Iron $\left(\mathrm{mg} \cdot \mathrm{kg}^{-1}\right)$ & $3.73 \pm 0.069$ & $79.12 \pm 0.67$ & $114.34 \pm 2.11$ & $173.74 \pm 3.38$ \\
\hline Manganese $\left(\mathrm{mg} \cdot \mathrm{kg}^{-1}\right)$ & $1.86 \pm 0.047$ & $32.66 \pm 0.48$ & $78.55 \pm 1.94$ & $112.55 \pm 2.7$ \\
\hline Nickel $\left(\mathrm{mg} \cdot \mathrm{kg}^{-1}\right)$ & $1.11 \pm 0.021$ & $23.66 \pm 0.63$ & $39.33 \pm 0.87$ & $75.6 \pm 1.34$ \\
\hline Zinc $\left(\mathrm{mg} \cdot \mathrm{kg}^{-1}\right)$ & $12.18 \pm 0.15$ & $38.65 \pm 0.86$ & $76.55 \pm 2.24$ & $91.61 \pm 2.45$ \\
\hline Lead $\left(\mathrm{mg} \cdot \mathrm{kg}^{-1}\right)$ & $4.31 \pm 0.062$ & $8.86 \pm 0.32$ & $23.72 \pm 1.28$ & $22.44 \pm 1.55$ \\
\hline
\end{tabular}

the test against $1.55 \mathrm{mS} \cdot \mathrm{cm}^{-1}, 1.09 \%, 256 \mathrm{mg} \cdot \mathrm{kg}^{-1}, 55.68$ $\mathrm{mg} \cdot \mathrm{kg}^{-1}, 3.09 \mathrm{mg} \cdot \mathrm{kg}^{-1}$ and $56.76 \mathrm{mg} \cdot \mathrm{kg}^{-1}$ of the control, respectively.

\subsection{Enzyme Activity}

Cellulase and Urease activity in the control and the soil samples treated with various concentrations of effluents such as $10 \%, 50 \%$ and $100 \%$ were observed with the amendment of substrate and results were depicted in the Figure 2. Little information is available on the effect of industrial effluents on soil cellulase activity. In this direction, cellulase activity was enhanced in soils treated with the effluents of textile and sugar industry (Kannan and Oblisami, 1990b), cotton ginning mills (Narasimha, 1997), paper mill effluent and amendment addition (Chinnaiah et al., 2002), solid urban waste (Renukaprasanna et al., 2002) and sodium based black liquor from fiber pulping for paper making (Xiao et al., 2005) over untreated soils. The present results clearly indicate that the activity of cellulase was greatly enhanced in the distillery effluent amended soil over the control (Figure 2). By increasing the soil incubation period, the cellulase activity was increased upto 30 days interval, and was declined in all the soil samples. Cellulase activity of the $10 \%$ effluent amended soil sample at 0 day was $29.45 \mathrm{mg}$ GE $\mathrm{g}^{-1} 30 \mathrm{~m}^{-1}$, it was increased by $400 \%$ to $119.22 \mathrm{mg} \mathrm{GE}$ $\mathrm{g}^{-1} 30 \mathrm{~m}^{-1}$ at 30 days, and later declined by to $48.8 \mathrm{mg}$ $\mathrm{GE} \mathrm{g}^{-1} 30 \mathrm{~m}^{-1}$ in 90 days. Similar results were also observed in the rest of the concentrations. Control soil was nearly static. The test sample of 100 percent effluent treated soil exhibited $16 \%$ more cellulase activity over the control at 0 day interval, it was $37.88 \mathrm{mg} \cdot \mathrm{mg} \mathrm{GE} \mathrm{g}^{-1}$ $30 \mathrm{~m}^{-1}$ against $32.55 \mathrm{mg} \mathrm{mg} \mathrm{GE} \mathrm{g}^{-1} 30 \mathrm{~m}^{-1}$ of the control soil and same trend was continued at the rest of the incubation periods (Figure 2). Soil treated with $50 \%$ effluent has shown higher activity over $10 \%$ and $100 \%$ effluent treated soils. For instance, $50 \%$ soil sample showed $37.88 \mathrm{mg} \mathrm{GE} \mathrm{g}^{-1} 30 \mathrm{~m}^{-1}$ activity at 0 day against 


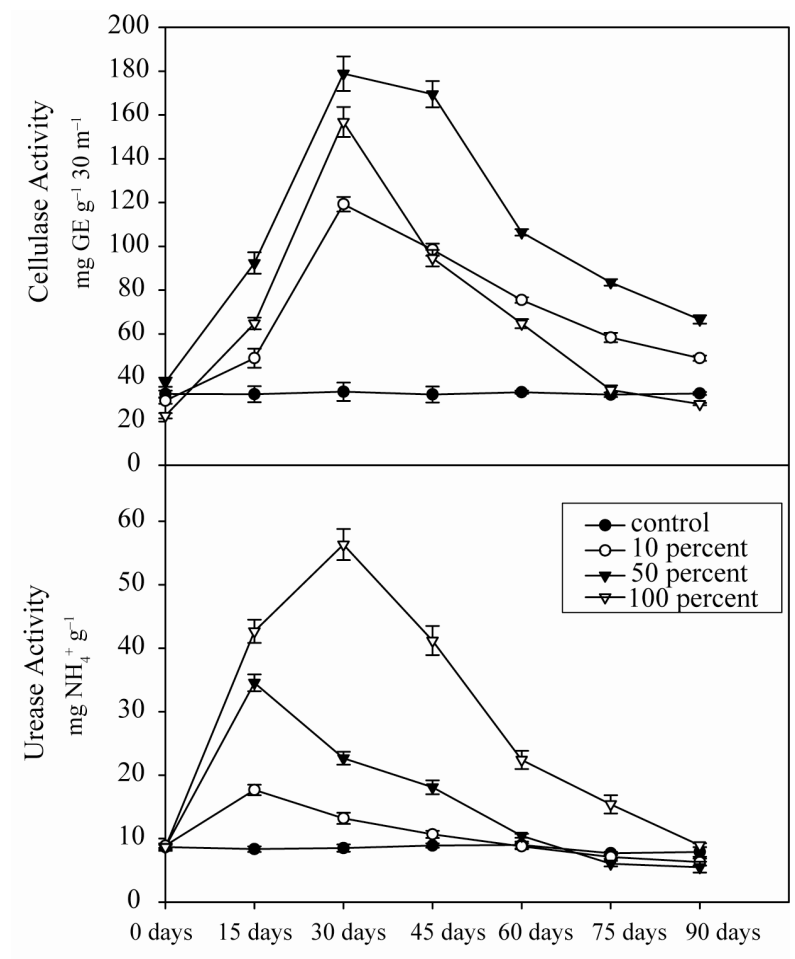

Figure 2. Cellulase and Urease activity in soil (with substrate) after incubation as influenced by different concentrations Distillery effluent (the mean values are presented, $n$ = 3).

$32.55,29.45$ and $22.56 \mathrm{mg} \mathrm{GE} \cdot \mathrm{g}^{-1} 30 \mathrm{~m}^{-1}$ activity of the control, $10 \%$ and $100 \%$ samples respectively. In terms of increasing percentage of activities, the $50 \%$ effluent treated sample has shown $400 \%, 50 \%$ and $15 \%$ more activities over the control, $10 \%$ and $100 \%$ effluent irrigated samples in 30 days, respectively. Similar trend was also seen at the rest of the incubations. Urease activity increased rapidly and reached the maximum level somewhat earlier in comparison to cellulase i.e. after 15 to 30 days in treated soils, although it remained constant in control treatment. The highest activity was in soil treated with the highest rate of effluent application nearly after 30 days of incubation. For other treatments its activity decreased significantly in 15 days for lower rate of treatment and after 30 days for higher rate of treatment. But the amended soil activity was always higher than control treatment. However, more interestingly at 75 and 90 days urease activity of distillery effluent amended soil was lower than control treatment. The highest values of enzyme activity were observed in high rates of effluent application, therefore we can express that increases or decreases of these enzymes is proportional to microbial biomass and available substrate which would increase by high organic matter (Nannipieri, 1994). In general, Cellulase and Urease activity can be divided in 2 stages, in the first stage its activity was dramatically upward and it was as a result of adding organic matter to the soil and the second stage lasting to the end of the incubation time in which a notable reduction in enzyme activity in soil treated with effluent was observed. For this stage we can express the effect of toxic compounds and metals. Enzymatic activity diminished with increasing available concentration of metals (Tyler, 1974; Kizilkaya et al., 2004). Increased levels of heavy metals will react of enzymes causing inhibition or inactivation of the enzymatic activity (Nannipieri, 1994). Metals also indirectly affect soil enzymatic activities by altering the microbial community which synthesizes enzymes (Kandeler et al., 1996). The organic matter-heavy metal fractions which are readily available for plant uptake, occur in organic matter and soil solutions. This would prevent the heavy metal from interacting directly with the active sites of enzyme, thus affecting the enzyme's activity (Doelman and Haanstra, 1984). The rapid decomposition of organic matter which occurs after the application of distillery effluent to soil increases the proportion of available metals as a result of mineralization of organically complexed metals (Dudley et al., 1986). Decreased activity of cellulase at higher concentrations of effluents may be due to the exposure of cell free enzyme to highly concentrated effluent. But, inhibitory effect of organic matter (Gianfreda and Bollag, 1994, 1996), high acidity (Ruggiero et al., 1996) and short living enzymes in the soil environment (Ahn et al., 2002) are also the reasons for the decreased activity. Similar observation was made by Sreenivasulu (2005) that, at high concentration of fungicide in soil, the cellulase activity was inhibited. According to Joshi et al. (1993), enzyme activity was greatly increased in soils high amount of substrate and increased enzyme activity was positively correlated with fungal, bacterial number and moisture content of litter. Nonetheless, high significant correlation between cellulase activity and soil respiration was observed by Splading (1979) and microbial biomass by Kanazawa and Miyashita (1987) and Donnelly et al. (1990). Additionally, by increasing the effluent concentration in the control sample, the cellulase activity was increased, maximum at $50 \%$, there after decreased.

\section{Conclusions}

The results of the present investigation clearly indicated that discharge of effluents from distillery has altered the physicochemical properties and enhanced the cellulase and urease activity of the soil, but it was declined with the time. Furthermore, by increasing the effluents concentration, the enzyme activity was improved upto 50\% and later decreased. Also, a suitable treatment of distillery effluent is essential to remove heavy metals and other 
toxic organic compounds. This observation, therefore, greatly warrants a prior treatment of distillery effluents before discharging on to agricultural land.

\section{Acknowledgements}

The authors are thankful to the University Grant Commission, New Delhi for their financial assistance and the Centre for Environmental Science \& Technology, BHU, Varanasi, for technical help.

\section{REFERENCES}

[1] A. Karaca, M. M. Haggblomb and R. L. Tate III, "Effects of the Land Application of Sewage Sludge on Soil Heavy Metal Concentrations and Soil Microbial Sewage Sludge and Soil Urease Activity 147 Communities," Soil Biology and Biochemistry, Vol. 31, 10, 1999, pp. 1467-1470. doi:10.1016/S0038-0717(99)00060-7

[2] A. E. Linkins, J. M. Mellio and R. L. Sinsabaugh, "Factors Affecting Cellulase Activity in Terrestrial and Aquatic Systems," American Society for Microbiology, Vol. 62, 1984, pp. 4693-4700.

[3] APHA, "Standard Methods for the Examination of Water and Waste Water," 21st Edition, American Public Health Association, Washington D.C., 2005.

[4] B. N. Richards, "The Microbiology of Terrestrial Ecosystems," Longman Scientific and Technical, Essex, 1987.

[5] B. P. Splading, "Effect of Divalent Metal Cations Respiration and Extractable Enzymes Activities of Douglas-Fir Needle Litter," Journal of Environmental Quality, Vol. 8, 1979, pp.105-109. doi:10.2134/jeq1979.81105x

[6] C. Aravena, C. Valentin, M. C. Diez, M. L. Mora and F. Gallardo, "Aplicación de lodos de planta de tratamiento de celulosa: efecto en algunas propiedades físicas y químicas de suelos volcánicos," Journal of Soil Science \& Plant Nutrition, Vol. 7, 2007, pp. 1-14.

[7] C. Xiao, M. Fauci, D. F. Bezdicek, W. T. McKean and W. L. Pan, "Soil Microbial Responses to Potassium-Based Black Liquor from Straw Pulping," Soil Science Society of America Journal, Vol. 70, 2005, pp. 72-77. doi:10.2136/sssaj2004.0339

[8] D. R. Rowe and I. M. Abdel-Magid, "Hand Book of Wastewater Reclamation and Reuse," CRC Press Inc. 550, 1995.

[9] D. W. Nelson, L. E. Sommers, "Total Carbon, Organic and Organic Matter," In: D. L. Sparks, Ed., Methods of Soil Analysis, Part 3. Soil Science Society of America Book Series, American Society of Agronomy and Soil Science Society of America, Madison, Wisconsin, Vol. 5, 1996, pp. 961-1010.

[10] E. Johansson, G. Krantz-Rulcker, B. X. Zhang and G. Oberg, "Chlorination and Biodegradation of Lignin," Soil Biology and Biochemistry, Vol. 32, 7, 2000, pp. 10291032. doi:10.1016/S0038-0717(00)00001-8

[11] E. Kandler, C. Kampichler and O. Horak, "Influence of
Heavy Metals on the Functional Diversity of Soil Microbial Communities," Biology and Fertility of Soils, Vol. 23, 3, 1996, pp. 299-306. doi:10.1007/BF00335958

[12] F. V. Kakhki, G. Hagnia and A. Lakzian, "Effect of Enriched Sewage Sludge on Soil Urease Activity," Soil and Environment, Vol. 27, No. 2, 2008, pp 143-147.

[13] G. Narasimha, G. V. A. K. Babu and B. Rajasekhar Reddy, "Physicochemical and Biological Properties of Soil Samples Collected from Soil Contaminated with Effluents of Cotton Ginning Industry," Journal of Environmental Biology, Vol. 20, 3, 1999, pp. 235-239.

[14] G. G. Hoffmann and K. Teicher, "Ein Kolorimetrisches Verfahren zur Bestimmung der Urease Activitat in Boden," Z. Pflanzenernahr. Bodenk, Vol. 91, 1961, pp. 55-63.

[15] G. W. Thomas, "Soil pH and soil acidity," In: D. L. Sparks, Ed., Methods of Soil Analysis, Part 3. Soil Science Society of America Book Series, American Society of Agronomy and Soil Science Society of America, Madison, Wisconsin, Vol. 5. 1996, pp. 475-490.

[16] H. A. Ajwa, C. J. Dell and C. W. Rice, "Changes in Enzyme Activities and Microbial Biomass of Tallgrass Prairie Soil as Related to Burning and Nitrogen Fertilization," Soil Biology and Biochemistry, Vol. 31, 5, 1999, pp. 769-777. doi:10.1016/S0038-0717(98)00177-1

[17] J. Rato Nunes, F. Cabral and A. López-Piñeiro, "Short-Term Effects on Soil Properties and Wheat Production from Secondary Paper Sludge Application on Two Mediterranean Agricultural Soils," Bioresource Technology, Vol. 99, 11, 2008, pp. 4935-4942. doi:10.1016/j.biortech.2007.09.016

[18] J. M. Bremner, and R. L. Mulvaney, "Urease Activity in Soil," In: R. G. Burns, Ed., Soil Enzymes, Academic Press, New York, 1978, pp. 149-196.

[19] K. Kannan and G. Oblisami, "Influence of Pulp and Paper Mill Effluents on Soil Enzyme Activities," Soil Biology and Biochemistry, Vol. 22, 1990, pp. 923-927. doi:10.1016/0038-0717(90)90130-R

[20] L. Gianfreda, J. M. Bollag, "Effect of Soils on the Behavior of Immobilized Enzymes," Soil Science Society of America Journal, Vol. 58, 1994, pp. 1672-1681. doi:10.2136/sssaj1994.03615995005800060014x

[21] L. Gianfreda and J. M. Bollag, "Influence of Natural and Anthropogenic Factors on Enzyme Activity in Soil," In: G. Stotzky and J. M. Bollag, Eds., Soil Biochemistry, Vol. 9, Marcel Dekker, New York, 1996, pp. 123-193.

[22] L. M. Dudley, B. L. McNeal and J. E. Baham, "TimeDependent Changes in Soluble Organics, Copper, Nickel, and Zinc from Sludge-Amended Soils," Journal of Environmental Quality, Vol. 15, 1986, pp. 188-192. doi:10.2134/jeq1986.00472425001500020020x

[23] M. Nagaraj, G. narsimha and V. Rangaswami, "Impact of Sugar Industry Effluent on Soil Cellulose, Activity," Intetnational Biodeterioration and Biodegradation, Vol. 63, 8, 2009, pp.1088-1092. doi:10.1016/j.ibiod.2009.09.006

[24] M. Renukaprasanna, H. T. Channal and P. A. 
Sarangamath, "Characterization of City Sewage and Its Impact on Soils and Water Bodies," 24th Symposium, 17th World Congress of Soil Science, Thailand, 14-21 August 2002.

[25] M. Sreenivasulu, "Interactions between Tridemorph and Captan (Fungicides) with Microorganisms in Ground Nut (Arachis hypogaea L.) Soils," M. Phil Thesis. Sri Krishna- devaraya University, Anantapur, India, 2005.

[26] M. L. Jackson, "The Text Book of Soil Chemical Analysis,” Prentice-Hall Inc, Engle Wood Cliffs, Jersy, 1973.

[27] M. Y. Ahn, J. Dec, J. E. Kim and J. M. Bollag, "Treatment of 2,4-Dichlorophenol Polluted Soil with Free and Immobilized Laccase," Journal of Environmental Quality, Vol. 31, 5, 2002, pp. 1509-1515. doi:10.2134/jeq2002.1509

[28] P. Nannipieri, "The Potential Use of Soil Enzymes as Indicators of Productivity, Sustainability and Pollution, Soil Biota Management in Sustainable Farming Systems," In: C. E. Pankhurst, B. M. Double, V. V. S. R. Gupta and P. R. Grace, eds., CSIRO, East Melbourne, 1994, pp. 238244.

[29] P. Ruggiero, J. Dec and J.M. Bollag, "Soil as a Catalytic System," In: G. Stotzky and J. M. Bollag, Eds., Soil Biochemistry, Marcel Dekker, New York, Vol. 9, 1996, pp. 79-122.

[30] P. K. Donnelly, J. A. Entry, Craw Ford Jr. and K. D. L. Cromack, "Cellulase and Lignin Degradation in Forest Soils Response to Moisture, Temperature and Acidity," Microbial Ecology, Vol. 20, 1990, pp. 289-295. doi:10.1007/BF02543884

[31] R. Albiach, R. Canet, F. Pomanes and F. Ingelmo, "Microbial Biomass Content and Enzymatic Activities after the Application of Organic Amendments to a Horticulture Soil," Bioresource Technology, Vol. 75, 1, 2000, pp. 43-48. doi:10.1016/S0960-8524(00)00030-4

[32] R. Kizilkaya, T. Askin, B. Bayarkli and M. Saglam, "Micro-Biological Characteristics of Soils Contaminated with Heavy Metals," European Journal of Soil Biology, Vol. 40, 2004, pp. 95-102. doi:10.1016/j.ejsobi.2004.10.002

[33] R. L. Cruz, A. M. Righetto and M. A. Nogueira, "Ex- perimental Investigation of Soil Groundwater Impacts Caused by Vinasse Disposal," Water Science Technology, Vol. 24, No. 11, 1991, pp. 77-85.

[34] S. Kanazawa and K. Miyashita, "Cellulase Activity in Forest Soil," Soil Science and Plant Nutrition, Vol. 33, 3, 1987, pp. 399-406.

[35] S. K. Pancholy and E. L. Rice, "Soil Enzymes in Relation to Old Field Succession: Amylase, Cellulase, Invertase, Dehydrogenase and Urease," Soil Science Society of American Proceedings, Vol. 37, 1973, pp. 47-50. doi:10.2136/sssaj1973.03615995003700010018x

[36] S. R. Joshi, G. D. Sharma and R. R. Mishra, "Microbial Enzyme Activities Related to Litter Decomposition Near a Highway in a sub tropical forest of North East India," Soil Biology and Biochemistry, Vol. 22, 1993, pp. 51-55.

[37] T. A. O'Brien, S. J. Herbert and A. V. Barker, "Growth of Corn in Varying Mixtures of Paper Mill Sludge and Soil," Communications in Soil Science and Plant analysis, Vol. 33, 2002, pp. 635-646. doi:10.1081/CSS-120002769

[38] U. Chinnaiah, M. Palaniappan and S. Augustine, "Rehabilitation of Paper Mill Effluent Polluted Soil Habitat: An Indian Experience," 24th Symposium, 17th World Congress of Soil Science, Thailand, 14-21 August 2002.

[39] U. J. Medhi, A. K. Talukdar and S. Deka, "Physicochemical Characteristics of Lime Sludge Waste of Paper Mill and Its Impact on Growth and Production of rice," Journal of Industrial Pollution Control, Vol. 21, No. 1, 2005, pp. 51-58.

[40] V. R. Ramakrishna Parama, M. Venkatesha and M. V. Bhargavi, "Recycling of Urban Domestic Residues as a Nutrient Source for Agriculture," 24th Symposium, 17th World Congress of Soil Science, Thailand, 14-21 August 2002.

[41] W. A. Dick, and M. A. Tabatabai, "Potential Uses of Soil Enzymes," In: F. B. Meting, Ed., Soil Microbial Ecology: Applications in Agricultural and Environmental Management, Marcel Dekker, New York. 1992. pp. 95-127.

[42] Y. P. Kalra and D. G. Maynard, "Methods Manual for Forest Soil and Plant Analysis," Information Report NOR-X-319 Forestry Canada, Northwest Region, Northern Forest Centre, Edmonton, Alberta, 1991. 